\title{
Effect of the Temperature Variation on Properties of Biodiesel and Biodiesel-Ethanol Blends Fuels
}

\author{
S.H. Park', S.H. Yoon' ${ }^{1}$ H.K. Suh' ${ }^{1}$ and C.S. Lee ${ }^{2^{*}}$ \\ 1 Graduate School of Hanyang University, Department of Mechanical Engineering, Hanyang University, \\ 17 Haengdang-dong, Sungdong-gu, Seoul, 133-791, Korea \\ 2 Department of Mechanical Engineering, Hanyang University, 17 Haengdang-dong, Sungdong-gu, Seoul, 133-791, Korea \\ e-mail: psh7836@hanyang.ac.kr - ysh3790@hanyang.ac.kr - hksuh@hanyang.ac.kr - cslee@hanyang.ac.kr \\ * Corresponding author
}

\begin{abstract}
Résumé - Effet de la variation de la température sur les propriétés de carburants biodiesel et de mélanges biodiesel-éthanol - Cette étude a pour objectif de déterminer les effets de variations de température et de proportion d'éthanol dans un mélange biodiesel-éthanol sur les propriétés du carburant obtenu. L'ajout de l'éthanol à du biodiesel permet d'éviter l'inconvénient du démarrage à froid connu dans le cas du biodiesel. De plus, les variations de température influent sur le comportement du spray et les caractéristiques de la combustion et des émissions dans la chambre de combustion. La viscosité cinématique et la densité ont été obtenues respectivement par la mesure de la viscosité dynamique et de la gravité spécifique.

Dans cette étude, on a pu observer que la gravité spécifique et la densité ont diminué linéairement lorsque la température et le taux d'éthanol dans le mélange ont augmenté. Une équation empirique a pu être obtenue à partir des valeurs mesurées ; c'est une fonction du second ordre du taux de mélange et du premier ordre de la température du mélange. Par ailleurs, les viscosités dynamiques et cinématiques ont diminué exponentiellement avec l'augmentation de la température. Basée sur ces mesures de viscosités, l'équation empirique, qui est fonction de la température, peut être étendue à chaque taux d'éthanol dans le mélange.
\end{abstract}

\footnotetext{
Abstract - Effect of the Temperature Variation on Properties of Biodiesel and Biodiesel-Ethanol Blends Fuels - The purpose of this study is to investigate the effect of the temperature variation and blending ratios on fuel properties of biodiesel and biodiesel blended with ethanol fuel. Adding the ethanol to biodiesel fuel can be improved the disadvantage of cold-starting of biodiesel fuel. Furthermore, properties which depend on the change of fuel temperature affect the spray behavior, combustion and emission characteristics in combustion chamber. The kinematic viscosity and density were obtained by the measured dynamic viscosity and specific gravity, respectively.

In this study, it was revealed that the specific gravity and density decreased linearly when the fuel temperature and the ethanol blending ratio increased. Empirical equation can be derived from the measured values and it is the function of the second order of blending ratio and the first order of fuel temperature. On the other side, the dynamic and kinematic viscosity decreased exponentially as rising of the fuel temperature. Based on the measured value of viscosities, the empirical equation which is the function of fuel temperature can be derived at each ethanol blending fuels.
} 


\section{INTRODUCTION}

Increasing of the energy consumption and drain of the fossil fuel are sufficient to arouse mankind to promotion of concerning about the renewable energy. Recently, the origin of a high oil price is prospected to a crude oil guarantee of main consumption country and the limitation of petroleum production ability.

Accordingly, development and supply of the new and renewable energy are more active at all the countries over the world. The renewable oxygenated fuels are also essential to achieve the reduction of carbon dioxide discharging due to the environmental regulation of each country. The most interesting fuels among the renewable energies are biodiesel and bioethanol. Biodiesel fuel is helpful to environment due to producing from renewable sources such as vegetable oil or animal fats and has a characteristic of a lower air-pollution compared to fossil fuel. Biodiesel fuel is able to improve the combustion process by the complete combustion compared to diesel fuel, because high cetane number of biodiesel makes better ignition ability and improvement of engine operating noise and good starting characteristics. Properties of soybean methyl esters are different compared to a conventional diesel fuel, and the density and viscosity are higher than those of diesel fuel. This could potentially have an impact on the injection quantity in a diesel engine fuel injection system. On a mass basis, neat biodiesel has approximately $13 \%$ less energy than typical diesel fuel. This energy loss is caused by the oxygen contained in biodiesel approximately $11-15 \%$ of molecular weight and lower heating value (Bechtold, 2002).

Ethanol fuel is a representative alternative fuel with biodiesel fuel. Biodiesel fuel is made of a vegetable oil abstracted from soybean, palm and rapeseed etc., while ethanol fuel is made of glucose derived from starch crops such as a sugarcane, wheat and corn. Like biodiesel fuel, ethanol fuel is also environmental friendly fuel and always renewable energy source because it is from a plant. The biomass, biodiesel and ethanol, have become an interested object of research until now. Therefore, many researchers are studying about spray, combustion and emission characteristics as well as properties of biodiesel and diesel (Suh et al., 2004; Yoon et al., 2005). Lee et al. (2005) studied the atomization and combustion characteristics using biodiesel blended fuels. In their study, they reported that there is little difference in the spray tip penetrations according to the mixing ratio of the biodiesel. $\mathrm{HC}$ emissions can be reduced and $\mathrm{NO}_{\mathrm{x}}$ emissions are increased by using biodiesel-blended fuels. Moreover, researches on the diesel-biodiesel and diesel-ethanol blends fuel were actively reported due to the increase of concerning for the renewable energy as alternative energy, recently (Tate et al., 2006; Joshi et al, 2007; Allen et al., 1999; Yuan et al., 2004; Tat et al., 2000; Krisnangkura et al., 2006; Kerschbaum et al., 2004).
Especially, the properties about biodiesel-diesel blended fuels were investigated by Joshi et al. (2007), Allen et al. (1999), Yuan et al. (2004) and Tat et al. (2000). However, few studies about application of biodiesel and ethanol blending fuel in a direct injection diesel engine found in the literature. There are studies about combustion and emission characteristics, not properties of biodiesel-ethanol blending fuel. Guo et al. (2007) studied about the volatility of blended fuels of biodiesel and ethanol. Pang et al. (2006) and Shi et al. (2006) studied about the emission of biodiesel-ethanol blended fuels and reported that the biodiesel-ethanol blended fuel has a lower PM emission and higher $\mathrm{NO}_{\mathrm{x}}$ emission. However, despite of the importance of biodiesel-ethanol blend fuel, the study on properties was limited and insufficient. Especially, the measurement and analysis of physical property of biodiesel and its blends with ethanol fuel is very difficult because of its low temperature of volatilization characteristics.

The aim of this study is to investigate the effect of fuel temperature variation on fuel properties of the biodiesel fuel and biodiesel blended with ethanol fuel such as the specific gravity, density, dynamic and kinematic viscosity of the fuel. Especially, it was conducted to the effect of fuel temperature on the fuel properties in the temperature range of $0^{\circ} \mathrm{C}-70^{\circ} \mathrm{C}$ for considering the effect of injector and fuel supply line temperature. The test temperature was limited under $70^{\circ} \mathrm{C}$ due to the ethanol volatilization characteristics.

\section{EXPERIMENTAL APPARATUS AND PROCEDURE}

\subsection{Test Fuels}

In this study, eight kinds of test fuels such as a neat biodiesel and seven biodiesel-ethanol blends were used for the analysis of the specific gravity, density and viscosity. Biodiesel derived from soy bean oil is a neat fuel which meets the standard of ASTM D 6751, and the ethanol with a degree of purity $99.9 \%$ meets the standard of ASTM D 5798. In the mixing process of fuels, the mixed fuels were stirred continuously for fuel uniformity at room temperature and pressure. After blending process, blends were stored in the brown bottle for preventing the oxidization with ambient air and were used within one-day. Table 1 shows the specifications of biodiesel and ethanol fuel and Table 2 shows the composition and notation of blending fuels.

\subsection{The Measurement of the Specific Gravity and Viscosity}

The specific gravity is defined as the ratio between the density of standard material (universally, the water of $4^{\circ} \mathrm{C}$, $\rho_{\mathrm{H} 2 \mathrm{O}}=1000 \mathrm{~kg} / \mathrm{m}^{3}$ ) and the density of test material $\left(\mathrm{SG}=\rho / \rho_{\mathrm{H} 2 \mathrm{O}}\right)$. The hydrometer using the Archimedes' principle measured the specific gravity of liquid from the mass of 
material and its buoyancy in the test liquid. The hydrometer used in this study weighted at one end, and measured the specific gravity according to the degree of sinking.

TABLE 1

Specifications of biodiesel and ethanol fuels

\begin{tabular}{l|c|c}
\hline \multicolumn{1}{c|}{ Fuel property } & ${\text { Biodiese }{ }^{1}}^{1}$ & Ethanol $^{2}$ \\
\hline Formula & $\mathrm{C}_{18}$ to $\mathrm{C}_{19}$ & $\mathrm{C}_{2} \mathrm{H}_{5} \mathrm{OH}$ \\
Molecular weight & 300 (approx.) & 46.07 \\
Composition, weight $\%$ & & \\
Carbon & 78 & 52.2 \\
Hydrogen & 11 & 13.1 \\
Oxygen & 11 & 34.7 \\
Sulfur & 0.01 to 0.0024 & - \\
Density, $\mathrm{kg} / \mathrm{L}$, at $15^{\circ} \mathrm{C}$ & 0.87 & 0.79 \\
Specific gravity & 0.87 & 0.79 \\
Pour point $/ \mathrm{melting} \mathrm{point,}{ }^{\circ} \mathrm{C}$ & $-3 /-$ & $-/-114.3$ \\
Boiling point, ${ }^{\circ} \mathrm{C}$ & 315 to 350 & 78.4 \\
Viscosity, $\mathrm{mPaS}$ at $20^{\circ} \mathrm{C}$ & $3 \sim 6$ & 1.2 \\
Lower heating value, $1000 \mathrm{KJ} / \mathrm{L}$ & $\sim 32$ & 21.1 \\
Centane number & $48-65$ & 8 \\
Octane number & -25 & 111 \\
Autoignition, ${ }^{\circ} \mathrm{C}$ & 225 & 420 \\
\hline
\end{tabular}

1 Biodiesel handling and use guidelines Energy Efficiency and Renewable Energy DOE/GO-102006-2358, third edition, September 2006.

2 Alternative fuels-Transportation fuels for today and tomorrow, Richard L. Bechtold, SAE international

TABLE 2

Test fuels

\begin{tabular}{l|c}
\hline \multicolumn{1}{c|}{ Fuel type } & Notation \\
\hline Biodiesel (methyl ester from soybean oil) 100\% & BDE0 \\
Biodiesel 95\% + Ethanol 5\% (Vol.) & BDE5 \\
Biodiesel 90\% + Ethanol 10\% (Vol.) & BDE10 \\
Biodiesel 85\% + Ethanol 15\% (Vol.) & BDE15 \\
Biodiesel 80\% + Ethanol 20\% (Vol.) & BDE20 \\
Biodiesel 70\% + Ethanol 30\% (Vol.) & BDE30 \\
Biodiesel 60\% + Ethanol 40\% (Vol.) & BDE40 \\
Biodiesel 50\% + Ethanol 50\% (Vol.) & BDE50 \\
\hline
\end{tabular}

The heat band and electric refrigeration system were installed around the measuring cylinder in order to change the fuel temperature from $0^{\circ} \mathrm{C}$ to $70^{\circ} \mathrm{C}$. Respectively, the heat band was used to change the fuel temperature range from $20^{\circ} \mathrm{C}$ to $70^{\circ} \mathrm{C}$ and the electric refrigeration system was used from $0^{\circ} \mathrm{C}$ to $20^{\circ} \mathrm{C}$. The fuel temperature was measured from two K-type thermocouples (Omega, KMTSS-020G-12) which are installed at the upper and lower of the measuring cylinder. For the accuracy of experiment, the specific gravity was measured when the difference of thermocouples reaches within $\pm 0.1{ }^{\circ} \mathrm{C}$, and the top of measuring cylinder was covered with a cap to prevent the evaporation of ethanol and biodiesel fuels.

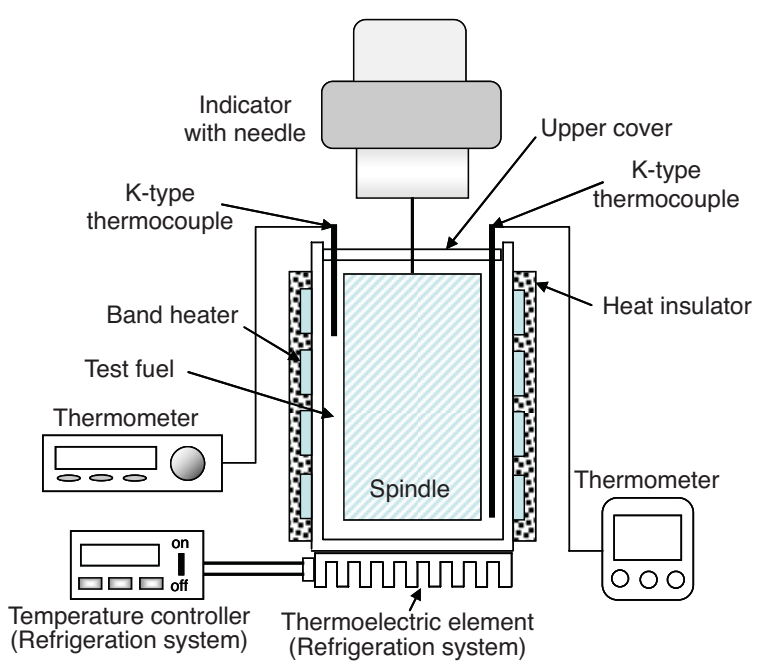

Figure 1

Schematic of the viscometer.

The dynamic viscosity of test fuels was measured by the viscometer (Brookfield, LVT) and the ultra low viscosity (UL) adapter (Brookfield, ULA-36). The viscometer consists of the main body with indicator needle and stand, and the UL adapter consists of a precision cylindrical spindle rotating inside an accurately machined tube as shown in Figure 1. The viscometer used in this study is possible to measure from 1.0 to $2.0 \times 10^{6} \mathrm{cP}$ at the spindle speed of $0.3-60 \mathrm{rpm}$. Viscosity is measured by the internal friction of a fluid. This friction becomes apparent when a layer of fluid is made to move in relation to another layer. The greater friction occurs, the greater amount of force is required to cause the spindle rotation. The measurement of the dynamic viscosity is possible to read from the needle of indicator when the rotation of spindle was a stable at given rotating speed. In the same way, the band heater and electric refrigeration system were installed to investigate the effect of the fuel temperature on the dynamic viscosity. The sample tube was covered with the heater band, and was installed to adiabatic insulator for maintaining the temperature. The K-type thermocouple with $0.5 \mathrm{~mm}$ diameter was installed to the inside of sample tube for the precise measurement of the fuel temperature. Measurements were performed in the temperature range of $0^{\circ} \mathrm{C}-70^{\circ} \mathrm{C}$ in steps with $5^{\circ} \mathrm{C}$. A digital thermometer (Omega, 2168A) indicates the fuel temperature from the thermocouple. The quantity of the test fuel in sample tube is $16 \mathrm{ml}$, and the sample tube was washed for the measuring accuracy at each experimental cases. Also, all of tests were performed in the test chamber for minimizing of the outside factors such as room temperature, humidity and dust. The measurement of viscosity was conducted as shown in Table 3. In this investigation, the conversion factor (namely, $\mathrm{K}$-factor) is used to calculate the dynamic viscosity in unit of centipoise (cP, $\mathrm{mPa} \cdot \mathrm{s})$ from the gauge as follows: 
the viscometer dial reading value $\times$ conversion factor $=$ the dynamic viscosity $(\mathrm{mPa} \cdot \mathrm{s})$

Used experimental devices in this work, such as the viscometer and hydrometer, have a measurement error about $\pm 1 \%$.

TABLE 3

Set-up for viscosity measurements

\begin{tabular}{c|c|c}
\hline Spindle speed (RPM) & Shear rate $\left(\mathrm{s}^{-1}\right)$ & Conversion factor $(\mathrm{K})$ \\
\hline 30.0 & 36.69 & 0.2 \\
12.0 & 14.68 & 0.5 \\
\hline
\end{tabular}

\section{EXPERIMENTAL RESULTS AND DISCUSSION}

\subsection{Cold Flow Characteristics}

The weakness of cold-start characteristics of the biodiesel engine as the one of disadvantages of biodiesel fuel can be improved adding the ethanol fuel (Shudo et al., 2005). Figure 2 shows the change of the cloud point as the adding the ethanol fuel to biodiesel fuel. Cloud point is the temperature at which small solid crystals are observed at first as the fuel is cooled (US DOE, 2006). The measurement of the cloud point is a very subjective. Therefore, in this experiment, the cloud point was defined the temperature point when the character on the reverse side of the test tube was disappeared due to the formation of crystal wax as shown in Figure 3. As illustrated in Figure 2, the cloud point of biodiesel-ethanol blending fuels decreased when the ethanol contents of mixture fuels increase. This means that the cold flow characteristics of biodiesel mixture fuel can be improved from adding the ethanol fuel.

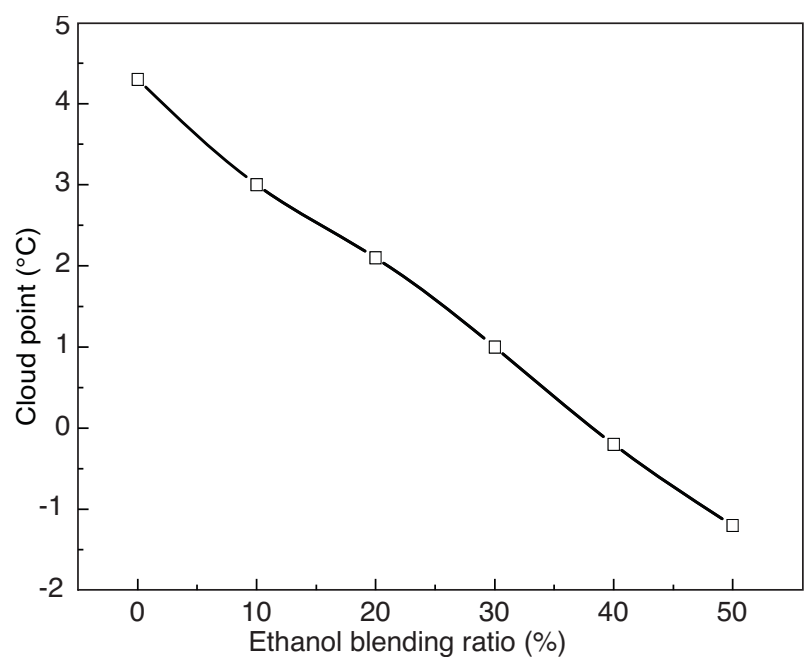

Figure 2

Cloud point with ethanol blended biodiesel.

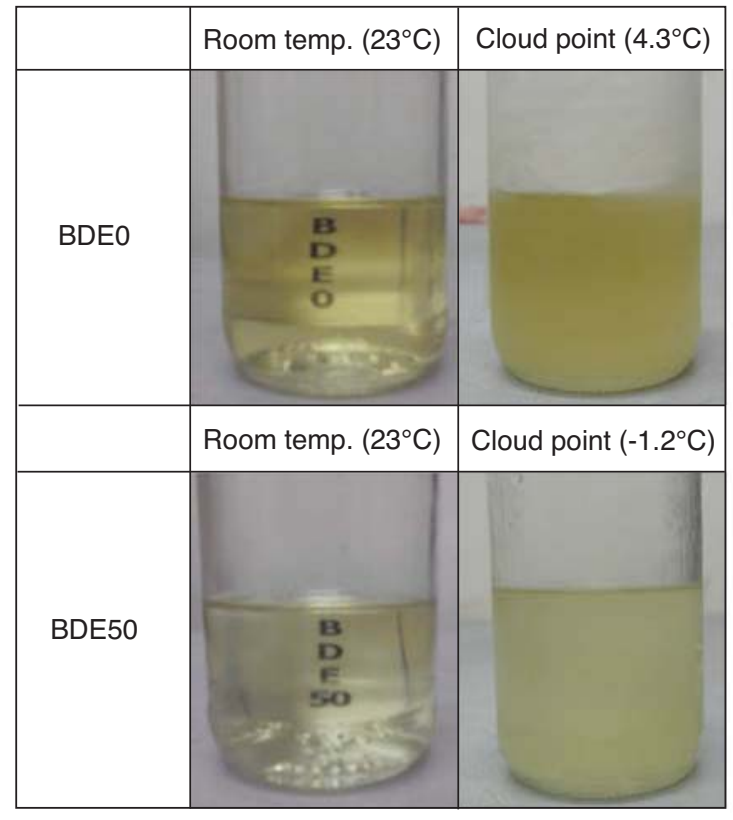

Figure 3

Pictures of BDE0 and BDE50 at the room temperature and the cloud point temperature.

\subsection{The Specific Gravity and Density}

The specific gravity and density are the most basic and important properties because it is correlated with some important performance such as cetane number and heating value. In this study, the density was calculated from the measured specific gravity as follows: the density of test material $\left(\mathrm{kg} / \mathrm{m}^{3}\right)$ is obtained by multiplication of the measured specific gravity and the density of standard material.

Figure 4 illustrates the change of densities in accordance with fuel temperature and blending ratio. In this figure, the symbol represents a measured value and the solid line represents a calculated value from the empirical Equation 1. The density is in inverse proportion to the fuel temperature as a linear. From the measured result of density, the density can be represented as following Equation 1:

$$
\rho_{\text {empirical }}=\alpha+\beta T
$$

In Equation 1, $\rho_{\text {empirical }}$ is a calculated density $\left(\mathrm{kg} / \mathrm{m}^{3}\right)$, $\alpha$ and $\beta$, are a correlation constant and $T$ is a fuel temperature $\left({ }^{\circ} \mathrm{C}\right)$. Equation 1 for each blending fuels is the function of the fuel temperature. Table 4 shows the general expression about each test fuels. As shown in Table 4, the lowest correlation coefficient-square $\left(R^{2}\right)$ is 0.9928 , which represents very good agreement between the measured value and calculated value from Equation 1. 


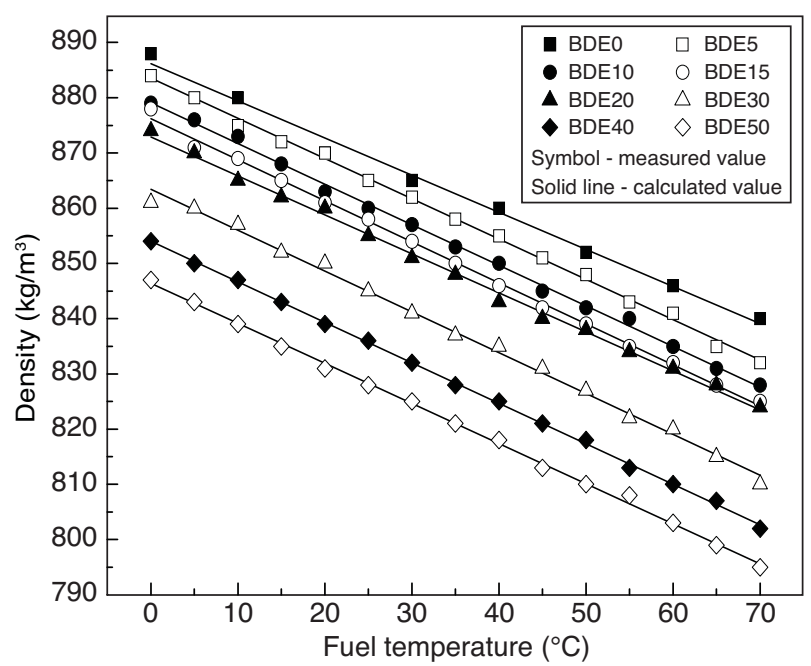

Figure 4

Densities of blending fuels and biodiesel fuel according to the fuel temperature and ethanol blending ratio.

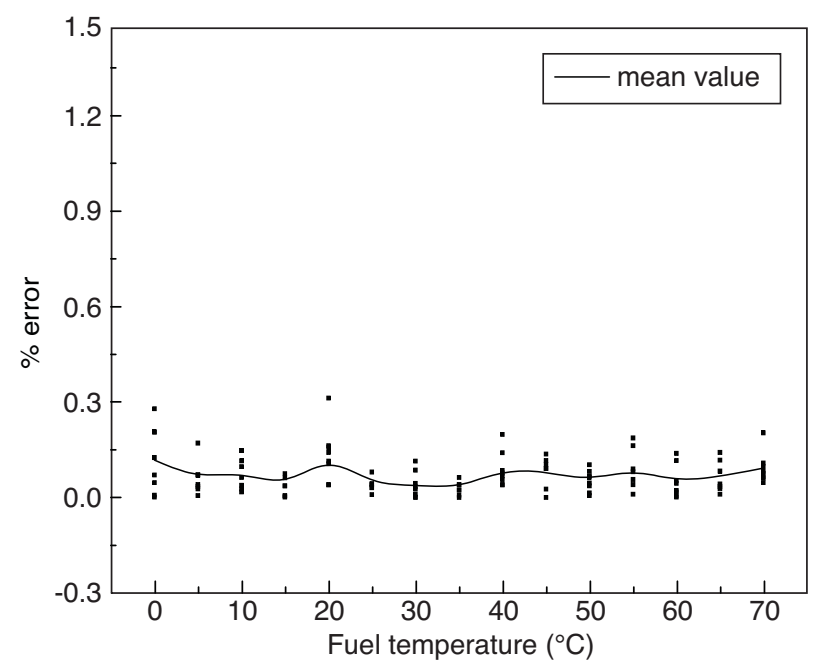

Figure 5

The percent error between the measured and calculated density value.
TABLE 4

Correlation constants for density equation over the temperature range of $0-70^{\circ} \mathrm{C}$

\begin{tabular}{l|c|c|c}
\hline \multirow{2}{*}{$\begin{array}{l}\text { Fuel } \\
\text { type }\end{array}$} & \multicolumn{2}{|c|}{ Correlation constants } & \multirow{2}{*}{$\mathrm{R}^{2}$} \\
\cline { 2 - 3 } BDE0 & $\alpha$ & $\beta$ & \\
BDE5 & 886.17 & -0.6726 & 0.9928 \\
BDE10 & 883.59 & -0.7293 & 0.9979 \\
BDE15 & 876.06 & -0.7350 & 0.9980 \\
BDE20 & 872.90 & -0.7429 & 0.9980 \\
BDE30 & 863.40 & -0.7057 & 0.9971 \\
BDE40 & 854.01 & -0.7393 & 0.9958 \\
BDE50 & 846.4 & -0.7336 & 0.9993 \\
\hline
\end{tabular}

Figure 5 represents the percent error between the measured and calculated value for each blending fuels. At all test temperature range and blending ratio, the maximum error of both values is within $0.3 \%$, thereby, it can be known that the empirical equation for fuel density (Equation 1) is a very precise.

Based in Table 4 and Figure 4, it can be combined one empirical equation for fuel density depended by the fuel temperature and blending ratio as following:

$$
\begin{aligned}
\rho_{\text {com-emp }} & =887.56-0.8163 M_{R}-0.72682 T-0.00104 M_{R} T \text { (2) } \\
& +2.13409 \times 10^{-5} M_{R}^{2} T
\end{aligned}
$$

where $\rho_{\text {com-emp }}$ is the empirical density $\left(\mathrm{kg} / \mathrm{m}^{3}\right), M_{R}$ is the blending ratio of ethanol (5\%-50\%) and $T$ is the fuel temperature $\left({ }^{\circ} \mathrm{C}\right)$. This equation is a function of the second order for ethanol blending ratio $\left(M_{R}\right)$ and the first order for fuel temperature $(T)$. Table 5 shows the calculated density from the combined empirical Equation 2, the measured density and the absolute error (\%). As it can be known in Table 5, the maximum percent error is a $0.55 \%$ at $70^{\circ} \mathrm{C}$ of fuel temperature in BDE20. Obtained combined empirical equation is a very precise in all temperature range and test fuels mixing conditions.

Figure 6 shows the comparison between the calculated value from the combined empirical Equation 2 and the measured value, especially, BDE5, BDE30 and BDE50. The measured value (symbol) and the calculated value (solid line) are well matched in both blends. The density difference between BDE5 and BDE50 is almost constant about $37.0 \mathrm{~kg} / \mathrm{m}^{3}$ at the measured and calculated value, respectively. Additionally, the measured density of BDE50 decreased $6.14 \%$ $\left(52 \mathrm{~kg} / \mathrm{m}^{3}\right)$, while the calculated density of BDE50 decreased $6.00 \%\left(50.78 \mathrm{~kg} / \mathrm{m}^{3}\right)$ for the temperature range from $0^{\circ} \mathrm{C}$ to $70^{\circ} \mathrm{C}$. The reduction rate of the measured and calculated value is almost same. It also means that co-relationship between the measured and calculated value from Equation 2 is very high. Therefore, it can be concluded that this combined empirical equation can be applied to any fuel temperature and any blending ratio in the experimental conditions.

\subsection{The Dynamic Viscosity}

An undiluted biodiesel fuel has a high viscosity. The problem of using neat biodiesel fuel in the direct injection diesel engines relates to their high viscosity. The high viscosity will lead to blockage of fuel lines, filters, high nozzle valve opening pressures and poor atomization (Nwafor, 2004). The high viscosity of neat biodiesel fuel can be solved by blending of ethanol fuel. 
TABLE 5

Measured and calculated density of blending fuels over the temperature range of $0-70^{\circ} \mathrm{C}$

\begin{tabular}{|c|c|c|c|c|c|c|c|c|c|}
\hline \multirow{2}{*}{$\begin{array}{l}\text { Fuel } \\
\text { type }\end{array}$} & & \multicolumn{8}{|c|}{ Temperature $\left({ }^{\circ} \mathrm{C}\right)$} \\
\hline & & 0 & 10 & 20 & 30 & 40 & 50 & 60 & 70 \\
\hline \multirow[t]{3}{*}{ BDE0 } & $\rho_{\text {measured }}\left(\mathrm{kg} / \mathrm{m}^{3}\right)$ & 888 & 880 & 870 & 865 & 860 & 852 & 846 & 840 \\
\hline & $\rho_{\text {com-emp }}\left(\mathrm{kg} / \mathrm{m}^{3}\right)$ & 887.56 & 880.29 & 873.02 & 865.76 & 858.49 & 851.22 & 843.96 & 836.68 \\
\hline & Error $(\%)$ & 0.05 & 0.03 & 0.35 & 0.09 & 0.18 & 0.09 & 0.24 & 0.39 \\
\hline \multirow[t]{3}{*}{ BDE10 } & $\rho_{\text {measured }}\left(\mathrm{kg} / \mathrm{m}^{3}\right)$ & 879 & 873 & 863 & 857 & 850 & 842 & 835 & 828 \\
\hline & $\rho_{\text {com-emp }}\left(\mathrm{kg} / \mathrm{m}^{3}\right)$ & 879.40 & 872.05 & 864.69 & 857.34 & 849.99 & 842.65 & 835.29 & 827.94 \\
\hline & Error $(\%)$ & 0.05 & 0.11 & 0.19 & 0.04 & 0.00 & 0.08 & 0.03 & 0.01 \\
\hline \multirow[t]{3}{*}{ BDE20 } & $\rho_{\text {measured }}\left(\mathrm{kg} / \mathrm{m}^{3}\right)$ & 874 & 865 & 860 & 851 & 843 & 838 & 831 & 824 \\
\hline & $\rho_{\text {com-emp }}\left(\mathrm{kg} / \mathrm{m}^{3}\right)$ & 871.23 & 863.84 & 856.45 & 849.06 & 841.67 & 834.28 & 826.89 & 819.50 \\
\hline & Error $(\%)$ & 0.32 & 0.13 & 0.41 & 0.23 & 0.16 & 0.44 & 0.49 & 0.55 \\
\hline \multirow[t]{3}{*}{ BDE30 } & $\rho_{\text {measured }}\left(\mathrm{kg} / \mathrm{m}^{3}\right)$ & 861 & 857 & 850 & 841 & 835 & 827 & 820 & 810 \\
\hline & $\rho_{\text {com-emp }}\left(\mathrm{kg} / \mathrm{m}^{3}\right)$ & 863.07 & 855.68 & 848.30 & 840.91 & 833.52 & 826.13 & 818.74 & 811.35 \\
\hline & Error $(\%)$ & 0.24 & 0.15 & 0.2 & 0.01 & 0.18 & 0.11 & 0.15 & 0.17 \\
\hline \multirow[t]{3}{*}{ BDE40 } & $\rho_{\text {measured }}\left(\mathrm{kg} / \mathrm{m}^{3}\right)$ & 854 & 847 & 839 & 832 & 825 & 818 & 810 & 802 \\
\hline & $\rho_{\text {com-emp }}\left(\mathrm{kg} / \mathrm{m}^{3}\right)$ & 854.91 & 847.57 & 840.22 & 832.88 & 825.54 & 818.19 & 810.85 & 803.51 \\
\hline & Error $(\%)$ & 0.11 & 0.07 & 0.14 & 0.11 & 0.06 & 0.02 & 0.10 & 0.19 \\
\hline \multirow[t]{3}{*}{ BDE50 } & $\rho_{\text {measured }}\left(\mathrm{kg} / \mathrm{m}^{3}\right)$ & 847 & 839 & 831 & 825 & 818 & 810 & 803 & 795 \\
\hline & $\rho_{\text {com-emp }}\left(\mathrm{kg} / \mathrm{m}^{3}\right)$ & 846.74 & 839.49 & 832.24 & 824.98 & 817.73 & 810.47 & 803.27 & 795.96 \\
\hline & Error $(\%)$ & 0.03 & 0.06 & 0.15 & 0.00 & 0.03 & 0.06 & 0.03 & 0.12 \\
\hline
\end{tabular}

Error $=100 \times \mid($ measured density - calculated density $) /$ measured density $\mid$.

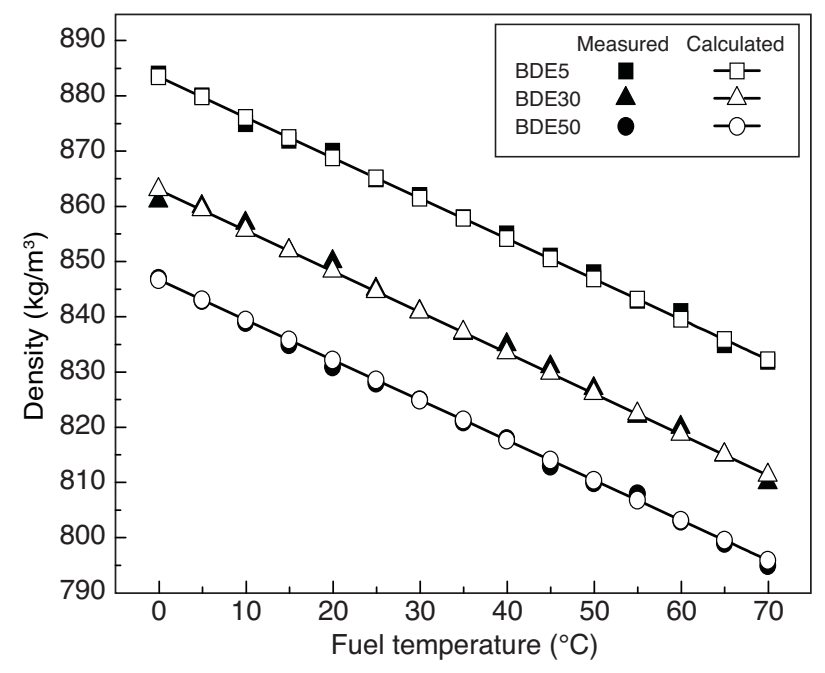

Figure 6

Comparison between the values from the empirical equation (Equation 2) and the measured value (BDE 5, BDE30 and BDE 50).

The dynamic viscosity is the tangential force per unit area required to move on the horizontal plane with respect to the other at unit velocity when maintained a unit distance apart by the fluid. The dynamic viscosity means the degree of the sticky as the resistance against the fluid flow direction, while the

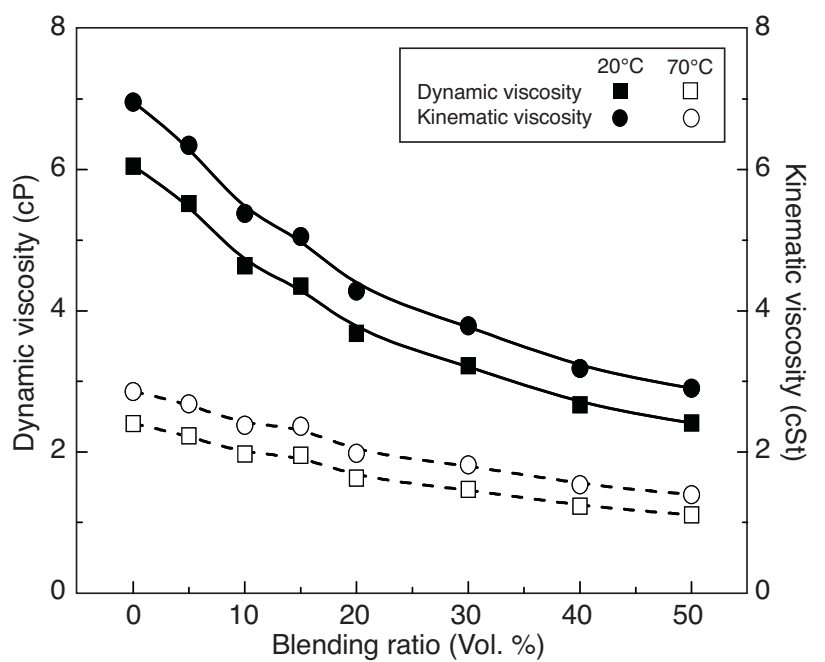

Figure 7

Viscosity dependent to blending ratio at $20^{\circ} \mathrm{C}$ and $70^{\circ} \mathrm{C}$ (measured value). kinematic viscosity means the barometer about how the fluid stream well. In addition, the kinematic viscosity has the meaning of the momentum diffusivity. If the value of the kinematic viscosity is large, the momentum and viscous effect diffuse rapidly, and the growth of the boundary layer is fast. 


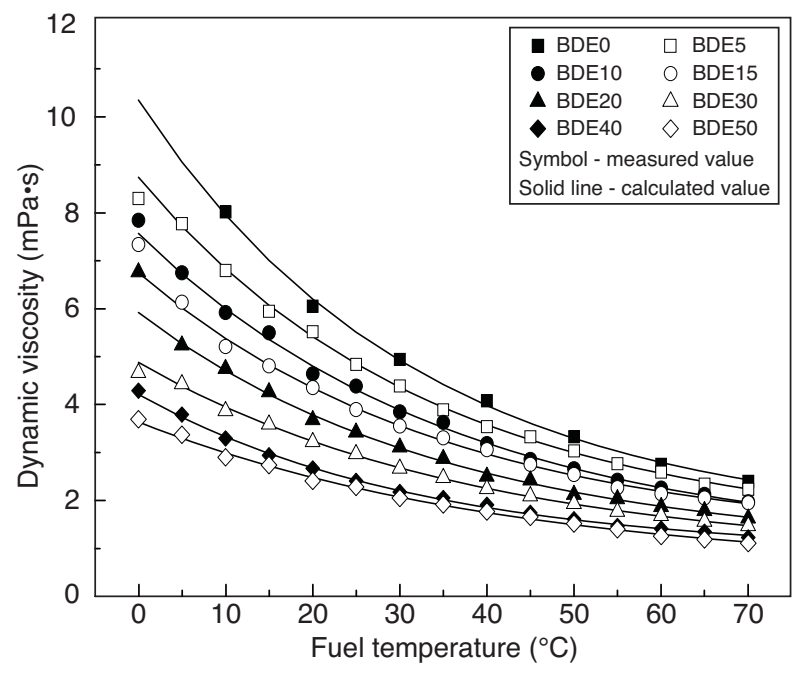

Figure 8

The dynamic viscosity of the blending fuels.

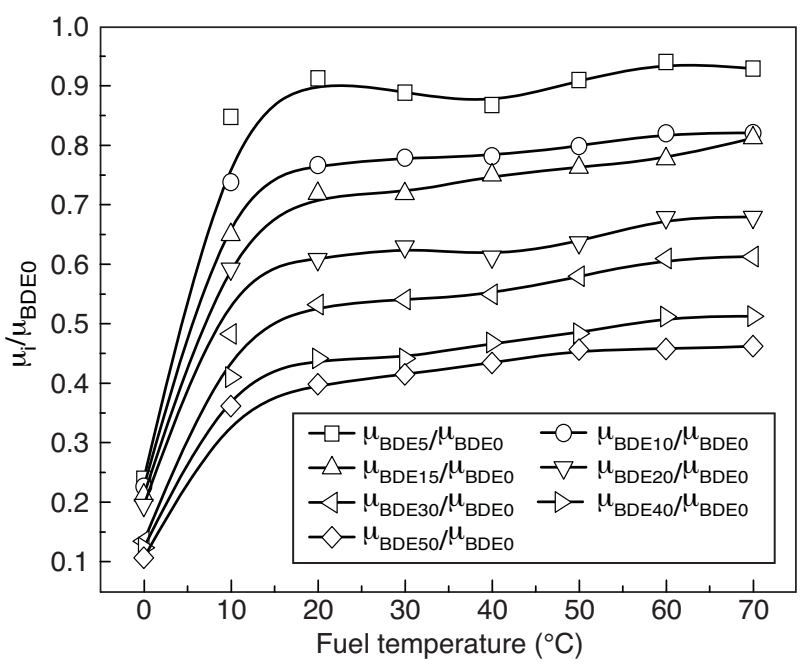

Figure 9

The ratio of the ethanol blending fuels against to the neat biodiesel fuel.

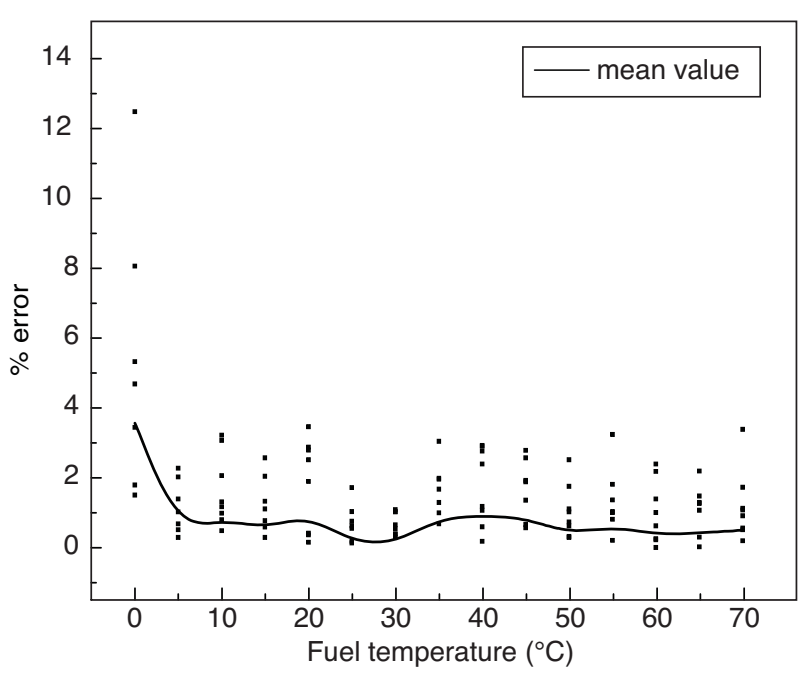

Figure 10

The percent error between the measured and calculated dynamic viscosity.

Two viscosities, dynamic and kinematic viscosities, decreased as increasing the ethanol blending ratio at constant fuel temperature as shown in Figure 7. As the results of adding the ethanol of $50 \%$ volumetric rate to pure biodiesel, the dynamic viscosity decreased about $60.16 \%$, the kinematic viscosity decreased about $58.29 \%$ at $20^{\circ} \mathrm{C}$. This is the reason that the ethanol of $99.9 \%$ purity has a low viscosity about 1.2 $\mathrm{mPa} \cdot \mathrm{s}$. On the other hand, at the fuel temperature of $70^{\circ} \mathrm{C}$, the dynamic viscosity decreased about $53.75 \%$, the kinematic viscosity decreased about $51.13 \%$.
As shown in Figure 8, the dynamic viscosity decreased exponentially according to increase of the fuel temperature. Additionally, the difference of the dynamic viscosity between the neat biodiesel fuel and other blending fuels gradually decreased as increasing of the fuel temperature, and the viscosity difference is close to zero at high fuel temperature. Through this result, test fuels have a nearly same value of the dynamic viscosity at high temperature. It can be said that the molecules movement of the fuels constructed by a polyatomic molecule moves energetically as the rising of fuel temperature. On the other hand, the value of the dynamic viscosity of an undiluted biodiesel fuel at $0^{\circ} \mathrm{C}$ was excluded, because the appearance of wax crystals at $0^{\circ} \mathrm{C}$ causes a large increase in the dynamic viscosity. Moreover, the higher blending ratio of ethanol affected the reduction of the dynamic viscosity because the dynamic viscosity of ethanol fuel is $1.2 \mathrm{mPa} \cdot \mathrm{s}$ at $20.0^{\circ} \mathrm{C}$ and its value is a lower than that of biodiesel, relatively. Thus, adding the liquid of the lower viscosity with the original liquid brings about the reduction of viscosity of the blending liquids. Figure 9 shows the ratio among the neat biodiesel and ethanol blending fuels. The ratio, represented a $\mu_{i} / \mu_{B D E 0}$ (where $i$ means each blending fuels such as BDE5, BDE10, BDE15, BDE20, BDE30, $\mathrm{BDE} 40$ and BDE50), has a value of $0-1$ as a dimensionless number. The mean of " 1 " is a similar characteristic in a dynamic viscosity. As shown in Figure 9, the ratio of dynamic viscosity increased before the fuel temperature of $15^{\circ} \mathrm{C}$, however, the ratio has a constant value after the fuel temperature of $15^{\circ} \mathrm{C}$ at each blending ratio. Contrary to the result of Figure 8, which the absolute value of dynamic viscosity converged a constant as rising of fuel temperature, the ethanol blending fuels have a peculiarity characteristic compared to a neat biodiesel fuel at each mixing ratio in the ratio aspect. 
TABLE 6

Correlation constants for dynamic viscosity equation over the temperature range of $5-70^{\circ} \mathrm{C}$

\begin{tabular}{l|c|c|c|c}
\hline \multirow{2}{*}{ Fuel type } & \multicolumn{3}{|c|}{ Correlation constants } & \multirow{2}{*}{$R^{2}$} \\
\cline { 2 - 4 } & $\alpha$ & $\beta$ & $\gamma$ & \\
\hline BDE0 & 8.92636 & 31.99697 & 1.42481 & 0.9983 \\
BDE5 & 7.42846 & 33.67224 & 1.31355 & 0.9989 \\
BDE10 & 6.58625 & 36.67122 & 0.98338 & 0.9974 \\
BDE15 & 5.60288 & 35.66137 & 1.14521 & 0.9970 \\
BDE20 & 4.96722 & 35.70214 & 0.9492 & 0.9981 \\
BDE30 & 4.0703 & 38.63232 & 0.80812 & 0.9989 \\
BDE40 & 3.32191 & 32.31106 & 0.89112 & 0.9982 \\
BDE50 & 3.12413 & 43.2401 & 0.81027 & 0.9960 \\
\hline
\end{tabular}

From the measured value of the dynamic viscosity, the empirical equation about each fuel can be derived as following:

$$
\eta_{\text {calculated }}=\alpha e^{\left(-\frac{T}{\beta}\right)}+\gamma
$$

Each empirical equation about blending fuels was shown in Table 6. Figure 10 shows the percent error between the measured and calculated dynamic viscosity about each blending fuels. As it can be seen in Figure 10, the absolute error is below $4 \%$ except $0^{\circ} \mathrm{C}$. Additionally, the lowest correlation coefficient-square $\left(R^{2}\right)$ is 0.9960 as Table 6. Table 7 shows in detail values of the measured and calculated from the empirical Equation 3.

\section{CONCLUSION}

The experiment was conducted to investigate the effect of the temperature on biodiesel - ethanol blending fuels properties such as the specific gravity, density, dynamic viscosity and kinematic viscosity. Based on the results from this work, the conclusions were obtained as following:

- The cloud point of biodiesel-ethanol blending fuels decreased when the ethanol contents of mixture fuels increase. This means that the cold flow characteristics of biodiesel blended with ethanol fuel can be improved in accordance with the increase of blending ratio of the ethanol fuel.

TABLE 7

Measured and calculated dynamic viscosity of blending fuels over the temperature range of $0-70^{\circ} \mathrm{C}$

\begin{tabular}{|c|c|c|c|c|c|c|c|c|c|}
\hline \multirow{2}{*}{\multicolumn{2}{|c|}{ Fuel type }} & \multicolumn{8}{|c|}{ Temperature $\left({ }^{\circ} \mathrm{C}\right)$} \\
\hline & & 0 & 10 & 20 & 30 & 40 & 50 & 60 & 70 \\
\hline \multirow[t]{3}{*}{ BDE0 } & $\eta_{\text {measured }}(\mathrm{mPa} \cdot \mathrm{S})$ & $*$ & 8.02 & 6.05 & 4.94 & 4.08 & 3.33 & 2.755 & 2.4 \\
\hline & $\eta_{\text {calculated }}(\mathrm{mPa} \cdot \mathrm{S})$ & $*$ & 7.95 & 6.20 & 4.92 & 3.98 & 3.30 & 2.79 & 2.43 \\
\hline & Error $(\%)$ & $*$ & 0.87 & 2.48 & 0.40 & 2.45 & 0.90 & 1.27 & 1.25 \\
\hline \multirow[t]{3}{*}{ BDE10 } & $\eta_{\text {measured }}(\mathrm{mPa} \cdot \mathrm{S})$ & 7.84 & 5.92 & 4.64 & 3.85 & 3.19 & 2.66 & 2.26 & 1.97 \\
\hline & $\eta_{\text {calculated }}(\mathrm{mPa} \cdot \mathrm{S})$ & 7.57 & 6.00 & 4.80 & 3.89 & 3.20 & 2.67 & 2.27 & 1.96 \\
\hline & Error $(\%)$ & 3.44 & 1.35 & 3.45 & 1.04 & 0.31 & 0.38 & 0.44 & 0.51 \\
\hline \multirow[t]{3}{*}{ BDE20 } & $\eta_{\text {measured }}(\mathrm{mPa} \cdot \mathrm{S})$ & 6.76 & 4.75 & 3.68 & 3.11 & 2.5 & 2.12 & 1.87 & 1.63 \\
\hline & $\eta_{\text {calculated }}(\mathrm{mPa} \cdot \mathrm{S})$ & 5.92 & 4.70 & 3.78 & 3.09 & 2.57 & 2.17 & 1.87 & 1.65 \\
\hline & Error $(\%)$ & 12.43 & 1.05 & 2.72 & 0.64 & 2.8 & 2.36 & 0 & 1.23 \\
\hline \multirow[t]{3}{*}{ BDE30 } & $\eta_{\text {measured }}(\mathrm{mPa} \cdot \mathrm{S})$ & 4.66 & 3.87 & 3.22 & 2.67 & 2.24 & 1.93 & 1.68 & 1.47 \\
\hline & $\eta_{\text {calculated }}(\mathrm{mPa} \cdot \mathrm{S})$ & 4.88 & 3.95 & 3.23 & 2.68 & 2.25 & 1.92 & 1.67 & 1.47 \\
\hline & Error $(\%)$ & 4.72 & 2.07 & 0.31 & 0.37 & 0.45 & 0.52 & 0.59 & 0 \\
\hline \multirow[t]{3}{*}{ BDE40 } & $\eta_{\text {measured }}(\mathrm{mPa} \cdot \mathrm{S})$ & 4.29 & 3.29 & 2.67 & 2.18 & 1.91 & 1.61 & 1.41 & 1.23 \\
\hline & $\eta_{\text {calculated }}(\mathrm{mPa} \cdot \mathrm{S})$ & 4.21 & 3.33 & 2.68 & 2.20 & 1.85 & 1.60 & 1.41 & 1.27 \\
\hline & Error $(\%)$ & 1.86 & 1.21 & 0.37 & 0.92 & 3.14 & 0.62 & 0 & 3.25 \\
\hline \multirow[t]{3}{*}{ BDE50 } & $\eta_{\text {measured }}(\mathrm{mPa} \cdot \mathrm{S})$ & 3.69 & 2.9 & 2.41 & 2.05 & 1.77 & 1.52 & 1.26 & 1.11 \\
\hline & $\eta_{\text {calculated }}(\mathrm{mPa} \cdot \mathrm{S})$ & 3.63 & 2.99 & 2.48 & 2.07 & 1.75 & 1.49 & 1.29 & 1.13 \\
\hline & Error $(\%)$ & 1.63 & 3.10 & 2.9 & 0.98 & 1.13 & 1.97 & 2.38 & 1.8 \\
\hline
\end{tabular}

Error $=100 \times \mid($ measured viscosity - calculated viscosity $) /$ measured viscosity $\mid$.

$*$ Large increase in viscosity for BDE0 at $0^{\circ} \mathrm{C}$ due to wax formation. 
- The specific gravity decreased linearly as rising of the fuel temperature. As adding to $20 \%$ volumetric ratio of ethanol fuel, the specific gravity decreased about $1.6 \%$ totally compared to the pure biodiesel.

- The empirical equation for ethanol blending ratio and fuel temperature is developed from the measured and calculated value of the density. It is the function of the second order for blending ratio and the first order for fuel temperature. This equation was well matched to the measured value as it can be known that the maximum percent error is $0.49 \%$.

- The dynamic is an inverse proportion to the fuel temperature, exponentially. Also, the dynamic viscosity decreased when the ratio of the ethanol fuel increases as volumetric rate.

- Properties of blends fuel (biodiesel + ethanol) can be predicted to the empirical equation from the measured value, which can be expressed the function of the fuel temperature and ethanol blending ratio.

\section{ACKNOWLEDGEMENTS}

This work was supported in part by the CEFV (Center for Environmentally Friendly Vehicle) of the Eco-STAR project of the MOE (Ministry of the Environment in Seoul, Republic of Korea). Also, this work was financially supported by the Ministry of Education and Human Resources Development (MOE), the Ministry of Commerce, Industry, and Energy (MOCIE), and the Ministry of Labor (MOLAB) through the fostering project of the Laboratory of Excellence. Also, this study was supported by the Second Brain Korea 21 Project in 2006.

\section{REFERENCES}

Allen C.A.W., Watts K.C., Ackman R.G., Pegg M.J. (1999) Predicting the viscosity of biodiesel fuels from their fatty acid ester composition, Fuel 78, 1319-1326.

Bechtold R.L. (2002) Alternative fuels, Published by Society of Automotive Engineers, Inc. (ISBN 0-7680-0907-3).
Gio Y., Zhong J., Xing Y., Li D., Lin R. (2007) Volatility of blended fuel of biodiesel and ethanol, Energ. Fuel. 21, 1188-1192.

Joshi R.M., Pegg M.J. (2007) Flow properties of biodiesel fuel blends at low temperatures, Fuel 86, 143-151.

Kerschbaum S., Rinke G. (2004) Measurement of the temperature dependent viscosity of biodiesel fuels, Fuel 83, 287-291.

Krisnangkura K., Yimsuwan T., Pairintra R. (2006) An empirical approach in predicting biodiesel viscosity at various temperatures, Fuel 85, 107-113.

Lee C.S., Park S.W., Kwon S.I. (2005) An Experimental Study on the Atomization and Combustion Characteristics of Biodiesel Blended Fuels, Energ. Fuel. 19, 5, 2201-2208.

Nwafor O.M.I. (1996) Performance of rapeseed oil blends in diesel engines, J. Appl. Energy 54, 4, 345-354.

Pang X., Shi X., Mu Y., He H., Shuai S., Chen H., Li R. (2006) Characteristics of arbonyl compounds emission from a dieselengine using biodiesel-ethanol-diesel as fuel, Atmos. Environ. 40, 7057-7065.

Shi X., Pang X.g, Mu Y., He H., Shuai S., Wang J., Chen H., Li R. (2006) Emission reduction potential of using ethanolbiodiesel-diesel fuel blend on a heavy-duty diesel engine, Atmos. Environ. 40, 2567-2574.

Shudo T., Fujibe A., Kazahaya M., Aoyagi Y., Ishii H., Goto Y., Noda A. (2005) The cold flow performance and the combustion characteristics with ethanol blended biodiesel fuel, Society of Automotive Engineers, SAE Paper 2005-01-3707.

Suh H.K., Park S.W., Kwon S.I., Lee C.S. (2004) Macroscopic behavior and atomization characteristics of bio-diesel fuels, $T$. KSAE 12, 6, 23-29.

Tat M.E., Van Gerpen J.H. (2000) The Specific Gravity of Biodiesel and Its Blends with Diesel Fuel, Oil Chem. Soc. 77, 2 , 115-119.

Tate R.E., Watts K.C., Allen C.A.W., Wilkie K.I. (2006) The densities of three biodiesel fuels at temperature up to $300^{\circ} \mathrm{C}$, Fuel 85, 1004-1009.

U.S. Department of energy (2006) Biodiesel handling and use guidelines, DOE/GO-102006-2358, 3rd edition.

Yoon S.H., Park S.W., Kim D.S., Kwon S.I., Lee C.S. (2005) Combustion and emission characteristics of biodiesel fuels in a common-rail diesel engine, Proceedings of ICEF05, ICEF20051258 .

Yuan W., Hansen A.C., Zhang Q. (2004) The specific gravity of biodiesel fuels and their blends with diesel fuel, Agricultural engineering international: the CIGR journal of scientific research and development, Manuscript EE 04 004, Vol. 4.

Final manuscript received in March 2008 Published online in August 2008

Copyright (C) 2008 Institut français du pétrole

Permission to make digital or hard copies of part or all of this work for personal or classroom use is granted without fee provided that copies are not made or distributed for profit or commercial advantage and that copies bear this notice and the full citation on the first page. Copyrights for components of this work owned by others than IFP must be honored. Abstracting with credit is permitted. To copy otherwise, to republish, to post on servers, or to redistribute to lists, requires prior specific permission and/or a fee: Request permission from Documentation, Institut français du pétrole, fax. +33147527078 , or revueogst@ifp.fr. 